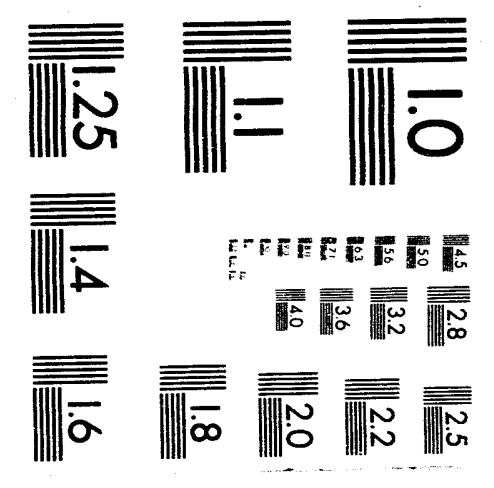



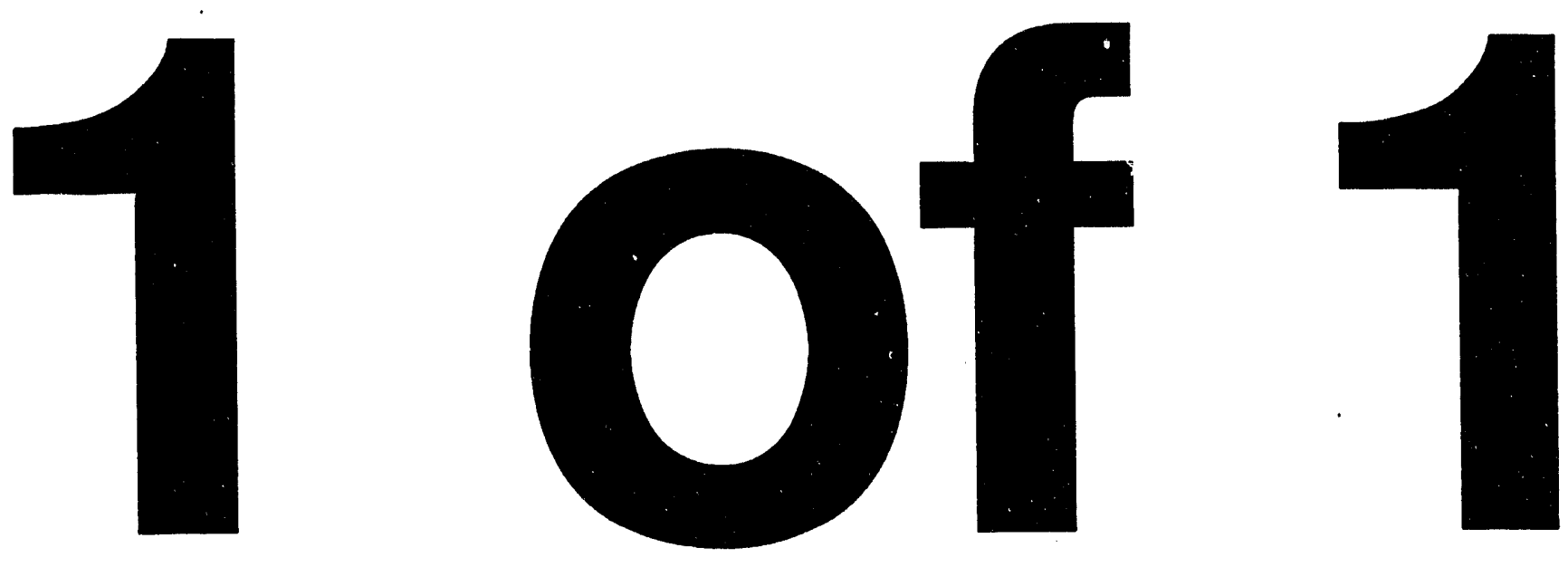


\title{
Scale-Up of Mild Gasification to a Process Development Unit
}

\section{Quarterly Report}

February 21 - May 20, 1993

\author{
J. A. L. Campbell \\ R. H. Carty \\ H. Foster
}

June 1993

Work Performed Under Contract No.: DE-FC21-91MC27391

For

U.S. Department of Energy

Office of Fossil Energy

Morgantown Energy Technology Center

Morgantown, West Virginia

By

Kerr McGee Coal Corporation

Oklahoma City, Oklahoma 


\section{DISCLAIMER}

This report was prepared as an account of work sponsored by an agency of the United States Government. Neither the United States Government nor any agency thereof, nor any of their employees, makes any warranty, express or implied, or assumes any legal liability or responsibility for the accuracy, completeness, or usefulness of any information, apparatus, product, or process disclosed, or represents that its use would not infringe privately owned rights. Reference herein to any specific commercial product, process, or service by trade name, trademark, manufacturer, or otherwise does not necessarily constitute or imply its endorsement, recommendation, or favoring by the United States Government or any agency thereof. The views and opinions of authors expressed herein do not necessarily state or reflect those of the United States Government or any agency thereof.

This report has been reproduced directly from the best available copy.

Available to DOE and DOE contractors from the Office of Scientific and Technical Information, 175 Oak Ridge Turnpike, Oak Ridge, TN 37831; prices available at (615) 576-8401.

Available to the public from the National Technical Information Service, U.S. Department of Commerce, 5285 Port Royal Road, Springfield, VA 22161; phone orders accepted at (703) 487-4650. 


\title{
Scale-Up of Mild Gasification to a Process Development Unit
}

\author{
Quarterly Report \\ February 21 - May 20, 1993
}

\author{
J. A. L. Campbell \\ R. H. Carty \\ H. Foster
}

Work Performed Under Contract No.: DE-FC21-91MC27391

\author{
For \\ U.S. Department of Energy \\ Office of Fossil Energy \\ Morgantown Energy Technology Center \\ P.O. Box 880 \\ Morgantown, West Virginia 26507-0880
}

\author{
By \\ Kerr McGee Coal Corporation \\ 123 Robert S. Kerr Avenue \\ Oklahoma City, Oklahoma 73102
}

June 1993 


\section{SUMMARY}

The work performed during the sixth quarterly reporting period (February 21, 1992 through May 20, 1993) on the research program, "Scale-Up of Mild Gasification to a Process Development Unit" is presented in this report. The overall objective of this project is to develop the IGT Mild-Gasification (MILDGAS) process for near-term commercialization. The specific objectives of the program are to:

- design, construct, and operate a 24-tons/day adiabatic process development unit (PDU) to obtain process performance data suitable for further design scaleup

- obtain large batches of coal-derived co-products for industrial evaluation

- prepare a detailed design of a demonstration unit

- develop technical and economic plans for commercialization of the MILDGAS process.

The project team that is performing the initial phases of the PDU development are: Kerr-McGee Coal corporation (K-M Coal), the Institute of Gas Technology (IGT), Bechtel Corporation (Bechtel), and Southern Illinois University at Carbondale (SIUC).

The MILDGAS process is a continuous closed system for producing liquid and solid (char) co-products at mild operating conditions up to $50 \mathrm{psig}$ and $1300^{\circ} \mathrm{F}$. It is capa le of processing a wide range of both eastern caking and western noncaking coals.

The 1 ton/hr PDU facility that is to be constructed is comprised of a 2.5-ft ID adiabatic gasifier for the production of gases, coal liquids, and char; a thermal cracker for upgrading of the coal liquids; a three-stage condensation train to condense and store the liquid products; and coal feeding and char handling equipment. The facility will also incorporate support equipment for environmentally acceptable disposal of process waste. 
This quarter we continued to assist DOE in the preparation of the Environmental Assessment documentation for the NEPA application. We reviewed and submitted our comments on the Environmental Assessment prepared by DOE for the NEPA review.

Also this quarter, we obtained permission from DOE to pursue the permitting needed to construct the PDU and we have started the preparation of the application document for the Illinois EPA Air Emissions permit. 


\section{TABLE OF CONTENTS}

Page

Introduction

1

Technical Discussion $\quad 4$

Task 1.0 Work and Environmental Plans 4 Objective 4

summary

Subtask 2.1 PDU Design Engineering 4

Şubtask 2.2 PDU Construction and Shakedown 4 objective 4

summary

Plans for Next quarter 4

Subtasks 2.2 through Task 6.0

Task 7.0 Project Management 5 Objective $\quad 5$

summary 


\section{INTRODUCTION}

Commercialization of the Institute of Gas Technology's Mild Gasification (MILDGAS) technology introduces a new industry into an economically depressed area. It utilizes a marginally marketable coal to produce char, in an environmentally acceptable manner, that can be used to make form coke, which is vitally needed in our metallurgical industry. It produces coal liquids which address import problems, and it also addresses the use of char for our electric utility industry. The specific objectives of the program are to: design, construct, and operate a 24-tons/day adiabatic process development unit (PDU) to obtain process performance data suitable for further design scaleup; obtain large batches of coal-derived co-products for industrial evaluation; prepare a detailed design of a demonstration unit; and develop technical and economic plans for commercialization of the MILDGAS process.

The MILDGAS process is capable of processing both eastern caking and western non-caking coals. The MILDGAS process is designed to offer options in the product slate by varying the process conditions and by blending different feed coals. The liquids, which can be processed as feedstocks for chemicals (e.g., BTX, phenol, cresols, xylenols, naphthalene, and indene), pitch for use as a binder for electrodes in the aluminum industry, and fuels. Depending on the feed coal characteristics and the operating conditions, the char can be used as an improved fuel for power generation or briquetted hot to make form coke for steel-making blast furnaces or for foundry cupola operations. The hot briquetting process offers options for blending various chars, coals and other additives (like alloying agents) to tailor the properties of the form coke. The mild gasification and briquetting processes are done entirely within closed vessels which offer significant advantages over conventional coking practices for control of fugitive emissions. 
The 1 ton/hr PDU facility that is to be constructed is comprised of a 2.5-ft ID adiabatic gasifier for the production of gases, coal liquids, and char; a thermal cracker for upgrading of the coal liquids; a three-stage condensation train to condense and store the liquid products; and coal feeding and char handing equipment. The facility will also incorporate support equipment for environmentally acceptable disposal of process waste.

Coal liquids from the PDU will be evaluated as feedstock for high-value chemicals and fuels by Reilly Industries, Inc. Reilly will also conduct separate modification operations such as thermal treatment with or without a Lewis Acid Catalyst, fractional distillation, and hydrotreating to produce specification-grade products. Reilly will take all the coal liquids produced at the PDU facility.

A major portion of the char produced will be used to make the form coke for blast furnaces and cupolas. The form coke for blast furnaces will be evaluated by several steel companies, including ITV and Armco. The form coke for use in a foundry cupola will be evaluated by General Motors Research Laboratories. In addition, the form coke will also be tested for foundry use at Pellet Technology Corporation's 60-inch cupola. The char from the PDU will also be evaluated at Southern Illinois University at Carbondale (SIUC) for relative reactivity and for suitability as a boiler fuel in a fluidized-bed combustor.

The product testing to be conducted in the program will yield a realistic assessment of the quality and economic value of both the coal liquids and solids produced. This input is required to update the market potential of the co-products and determine the slate of products and the economics of the demonstration and commercial plants for the MIIDGAs process. The project team for the PDU development are: K-M Coal, Institute of Gas Technology (IGT), Bechtel Corporation, SIUC, General Motors Corporation, Pellet Technology corporation (PTC), LTV, Armco, Reilly and Auto Research. 
$\mathrm{K}-\mathrm{M}$ Coal, which has large reserves of both eastern and western coals, is very much interested in near-term commercialization of the MILDGAS process. K-M Coal is responsible for the overall management and technical direction of the program. IGT, as the originator of the MILDGAS technology, is responsible for technology development, product evaluation management, and overall technical supervision. Bechtel Corporation is the A\&E firm responsible for the process and plant design and construction, development of a demonstration plant design, and input to the commercialization plan revision. SIUC operates the Illinois coal Development Park at Carterville, Illinois, which will be the location of the PDU. SIUC is responsible for operation of the PDU facility and for evaluation of the char product as a boiler fuel.

The State of Illinois is the major contributor of the cost sharing portion of this program. Their contribution is being supplemented by K-M Coal, SIUC, and GM. Contributions of Reilly and the steel companies are gratefully acknowledged but are not considered part of the cost sharing. All acceptable grades of form coke produced will be sold by Hickman williams co., the largest brokers for coke in the midwest. 
TECHNICAL DISCUSSION

Task 1.0 Work and Environmental Plans

objective: The objective of this task is to develop work and environmental plans for the project.

Summary: The Environmental Plan and NEPA Documentation consists of the data that are required by DOE for compliance with the National Environmental Policy Act (NEPA). This quarter, work has concentrated on assisting DOE in the preparation of the Environmental Assessment documentation for the NEPA application by clarifying questions on the PDU site and the estimated emissions. We have reviewed the Environmental Assessment documentation for the NEPA application and submitted our comments to DOE.

Tasks 2.1 Design Engineering

No work was scheduled on this task for this quarter.

Task 2.2 PDU Construction and Shakedown

objective currently, the only objective of this task that has been approved is the obtaining of the necessary permits to construct the PDU.

Summary This quarter, we requested and received permission from DOE to begin the permitting process. We have started preparation of the documentation necessary to obtain the permit to construct from the Illinois EPA. It is expected that this will consist only of permits for the air emission devices of the baghouses for the coal and char handling and the scrubber for the oxidizer effluent stream.

Plans for Next Quarter In the next quarter, it is expected that all of the documentation for obtaining the necessary permits to construct the PDU will be completed and submitted to the governing authorities. 


\section{Tasks 2.3 through Task 6.}

No work was scheduled on these tasks for this quarter.

\section{Task 7.0 Project Management}

objective The objectives of this task include the normal project management functions of planning, control, and reporting of project progress.

Summary This quarter, project management consisted of preparation and submittal of the usual monthly and quarterly reports. 

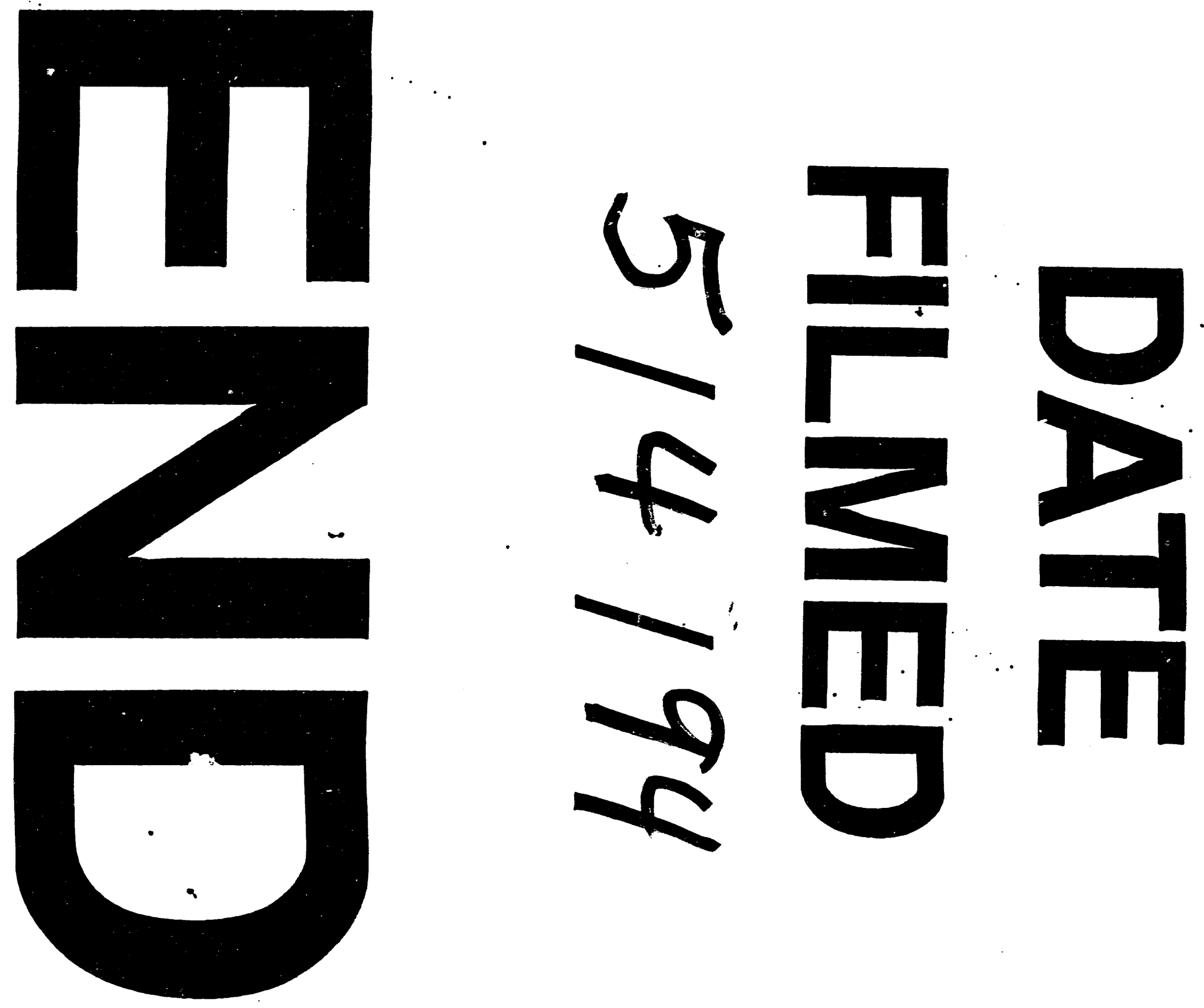


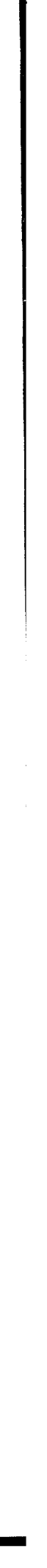

